\title{
Micro-blogging as Online Word of Mouth Branding
}

\section{Bernard J. Jansen}

College of Information Sciences and Technology

The Pennsylvania State University

jjansen@acm.org

\section{Mimi Zhang}

College of Information Sciences and Technology

The Pennsylvania State University

mzhang@ist.psu.edu

\section{Kate Sobel}

Smeal College of Business Administration

The Pennsylvania State University

kas5229@psu.edu

\section{Abdur Chowdury}

Twitter, Inc.

San Francisco, CA 94107 USA

abdur@ir.iit.edu

\section{Abstract}

In this paper, we report research results investigating micro-blogging as a form of online word of mouth branding. We analyzed 149,472 micro-blog postings containing branding comments, sentiments, and opinions. We investigated the overall structure of these micro-blog postings, types of expressions, and sentiment fluctuations. Of the branding micro-blogs, nearly 20 percent contained some expressions of

Copyright is held by the author/owner(s).

CHI 2009, April 4-9, 2009, Boston, Massachusetts, USA

ACM 978-1-60558-247-4/09/04. branding sentiments. Of these tweets with sentiments, more than 50 percent were positive and 33 percent critical of the company or product. We discuss the implications for organizations in using micro-blogging as part of their overall marketing strategy and branding campaigns.

\section{Keywords}

Micro-blogging, twittering, branding, social networking

\section{ACM Classification Keywords}

J.4 [Computer Applications]: Social and Behavioral Sciences - Economics

\section{Introduction}

Word-of-mouth is the process of conveying information from person to person. In commercial situations, wordof-mouth (WOM) involves consumers sharing details, their opinions, or reactions about businesses, products, or services with other people. This WOM branding is a captivating, influential, multifaceted, and typically hard to influence form of product marketing $[4,7,8]$. Positive WOM branding is considered as a powerful marketing medium for companies to influence consumers. WOM branding is based on social networking and trust: people rely on families, friends, and others in their social network fro commercial insights. Research also indicates that people appear to trust seemingly disinterested opinions from people 
outside their immediate social network, such as online reviews [5]. This is known as online WOM (OWOM) or electronic WOM (eWOM).

One new form of OWOM marketing is micro-blogging, using Web services such as Twitter. One paradigm for studying the constant connectivity of modern social network service in the commercial area is called the attention economy [3], where brands must constantly compete for the attention of potential and existing customers. In this attention economy, micro-blogging is a new form of communication through which users can describe things of interest and express attitudes that they are willing to share in short posts (i.e., microblogs). These posts are distributed via instant messages, mobile phones, email, or the Web.

Micro-blogging (a.k.a., micro-sharing or microupdating) has the potential to change branding and reputation management in OWOM campaigns from concept to reality. Micro-blogs are short textual comments usually delivered to a network of associates. Micro-blogging and Twittering (from the application, Twitter, by far the most popular micro-blogging application in this sector) are the act of posting microblogs. Tweets (micro-blogs on Twitter) may enter our lexicon just as Xerox has for copying and Google has for searching. For this paper, we will refer to this phenomenon as micro-blogging.

In this study, we examine the expressions of brand attitudes in micro-blog postings. However, there are several unanswered questions concerning this new topic. How prevalent are branding micro-blogs? How do people structure these micro-blogs? What are their effects on online reputation management? These are the questions that motivate our research.

\section{Prior Studies}

There has been limited published work in the microblogging area. Java, Song, Finin, and Tseng's [10] study is one of the few published works that we could locate. They studied the topological and geographical properties of Twitter's social network. The researchers found that people used micro-blogging to talk about their daily activities and to seek or share information. Also focusing on the social networking aspects, Huberman, Romero, and Fang [9] examined scarcity of attention and the daily activities that channel people into interacting with only a few people, which their study of Twitter bore out. Milstein and fellow researchers [12] present general background information on Twitter and micro-blogging. There are numerous popular press articles on leverage microblogging applications for a variety of purposes.

Much of the prior literature on OWOM branding has been on blogs, customer review sites, and Webpages. These are certainly aspects of OWOM, but there has been little prior work focusing on the unique features of the micro-blogging area. Micro-blogging is becoming increasingly important due to its immediacy to the product event, and the growing use of micro-blogging by an ever increasing group of potential customers. As such, micro-blogging will probably have increasing and positive influence on OWOM branding efforts.

\section{Research Question}

With this motivation, our research question is what are the overall trends of brand micro blogging? 


\begin{tabular}{|l|l|l|}
\hline $\begin{array}{c}\text { Industry } \\
\text { Sector }\end{array}$ & \multicolumn{1}{|c|}{$\begin{array}{c}\text { Major } \\
\text { Brand }\end{array}$} & Competitor \\
\hline Apparel & H\&M & $\begin{array}{l}\text { Banana } \\
\text { Republic }\end{array}$ \\
\hline Automotive & Toyota & Honda \\
\hline $\begin{array}{l}\text { Computer } \\
\text { Hardware }\end{array}$ & Dell & Lenovo \\
\hline $\begin{array}{l}\text { Computer } \\
\text { Software }\end{array}$ & Microsoft & Apple Leopard \\
\hline $\begin{array}{l}\text { Consumer } \\
\text { Electronics }\end{array}$ & Sony & Toshiba \\
\hline Energy & Exxon & Sunoco \\
\hline Food & Kellogg's & Cheerios \\
\hline $\begin{array}{l}\text { Internet } \\
\text { Service }\end{array}$ & Google & Yahoo! \\
\hline $\begin{array}{l}\text { Personal } \\
\text { Care }\end{array}$ & Oral-B & Crest \\
\hline Fast Food & Starbucks & McDonald's \\
\hline $\begin{array}{l}\text { Sporting } \\
\text { Goods }\end{array}$ & Adidas & Reebok \\
\hline Trans. & Fedex & DHL \\
\hline
\end{tabular}

\begin{tabular}{|l|l|l|}
\hline \multicolumn{1}{|c|}{$\begin{array}{c}\text { Industry } \\
\text { Sector }\end{array}$} & Product & \multicolumn{1}{|c|}{$\begin{array}{c}\text { Known } \\
\text { Brand }\end{array}$} \\
\hline Apparel & & TopShop \\
\hline Automotive & Prius & $\begin{array}{l}\text { SMART } \\
\text { ForTwo }\end{array}$ \\
\hline $\begin{array}{l}\text { Computer } \\
\text { Hardware }\end{array}$ & & Averatec \\
\hline $\begin{array}{l}\text { Computer } \\
\text { Software }\end{array}$ & $\begin{array}{l}\text { Windows } \\
\text { Vista }\end{array}$ & \\
\hline $\begin{array}{l}\text { Consumer } \\
\text { Electronics }\end{array}$ & BRAVIA & Magnavox \\
\hline Food & Special K & Malt-O-Meal \\
\hline $\begin{array}{l}\text { Internet } \\
\text { Service }\end{array}$ & Gmail & KartOO \\
\hline $\begin{array}{l}\text { Personal } \\
\text { Care }\end{array}$ & $\begin{array}{l}\text { Oral-B } \\
\text { Triumph }\end{array}$ & Aquafresh \\
\hline Fast Food & $\begin{array}{l}\text { Drive } \\
\text { Through }\end{array}$ & Arby's \\
\hline $\begin{array}{l}\text { Sporting } \\
\text { Goods }\end{array}$ & $\begin{array}{l}\text { Adidas } \\
\text { Originals }\end{array}$ & Saucony \\
\hline
\end{tabular}

To address this research question, we selected 50 brands and analyzed micro-blogs that mentioned these brands over 13 consecutive weeks. We algorithmically analyzed the expressions or sentiment of these microblogs and categorized them to determine aggregate characteristics of brand micro blogging expression.

\section{Research Design}

We used the Twitter Web application, one of the most popular micro-blogging services. However, all microblogging applications share a set of similar characteristics: (1) short text messages, (2) instantaneous message delivery, and (3) subscriptions to receive updates. So, although we used Twitter in this research, we believe our results to be applicable to other micro-blogging applications.

Twitter

Launched on July 13,2006 , Twitter is a micro-blogging service that allows users to send updates (a.k.a. tweets) to a network of friends (a.k.a. followers) from variety of devices. Tweets are text-based posts of up to 140 characters in length. The default setting for tweets is public, which permits people to follow and read each other's tweets without giving mutual permission.

Tweets are displayed on a user's profile page, or they can be delivered directly to followers via instant messaging, Short Message Service (SMS), Really Simple Syndication (RSS), email or through an application such as Twitterrific or Facebook. The Twitter application program interface (API) allows the integration of Twitter with other Web services and applications. Twitter is increasingly used by new organizations to receive updates during emergencies and natural disasters. As the largest, most well known, and most popular of the micro-blogging sites, Twitter was an ideal candidate for our study of micro-blogging's impact in the online branding area. As Twitter's user base has grown, it has attracted the attention of corporations and others interested in customer behavior and service.

\section{Brand List Development}

Given that we were interested in micro-blogging for branding purposes, we had to select key brands for investigation. We explored several lists of brands including The American Customer Satisfaction Index ${ }^{1}$, Business Week's Top Brand $100^{2}$, and BrandZ Top 100 Most Powerful Brands Ranking ${ }^{3}$.

To ensure a good cross segment sample, we employed an industry classification method used by Business Week to make sure the brands were spread across major industries, but we also kept the categories closely related with items from daily life, under the assumption that these would be the ones most likely of concern with micro-blogging. We also counter balanced this cross industry approach by trying to select the brands that provided similar products or services in order to make them more comparable (see sidebar).

\section{Data Collection and Analysis}

We collected these tweets using the Summize tool. Summize ${ }^{4}$ is a popular service for searching tweets and keeping up with emerging trends in real-time.

\footnotetext{
http://tinyurl.com/24c8hj

$2 \mathrm{http}: / /$ tinyurl.com/2e6nt

http://tinyurl.com/6hsth3

${ }^{4}$ Twitter acquired Summize in 2008
} 
We collected data from Summize for 13 weeks, from April 4, 2008 to July 3, 2008 . This gave us 650 reporting episodes (13 reporting periods $\times 50$ brands). For each brand in list in the sidebar, we submitted queries to Summize in the format: [brand name] since:[start date] until:[end date] to retrieve the sentiment for that week period.

Using Banana Republic as an example, the query for the week from April 4, 2008 to April 10, 2008 is Banana Republic since:2008-04-04 until:2008-04-10. We repeated this process for the same brand the following week until we collected data for all brands from all 13-week periods and for all brands.

Like Twitter, Summize offers an API, so other products and services can filter the constant queue of updates in a variety of ways. The Summize service analyzes tweet sentiment and gives the queried brand an overall sentiment rating for a given period using a five-point Likert scale and labeling each point from lowest to highest as wretched, bad, so-so, swell, and great.

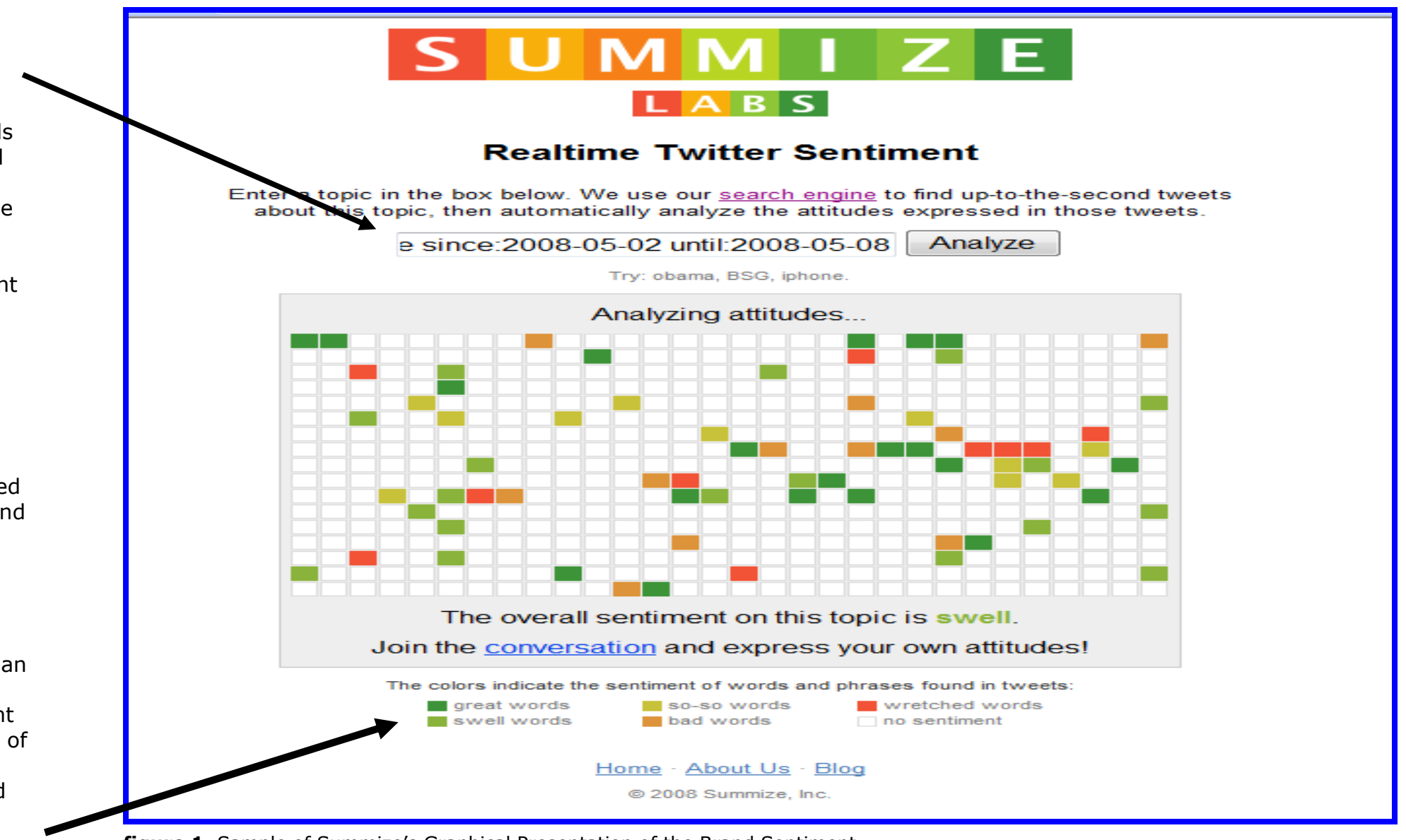

figure 1. Sample of Summize's Graphical Presentation of the Brand Sentiment

For each brand we calculated the classification of each tweet. Summize uses a lexicon of approximately 200,000 uni-grams and bi-grams of words and phrases that have a probability distribution to determine the sentiment of the brand for a given period. Summize trained its classifier with nearly 15 million views on topics ranging from movies to electronics, etc. The objective was to determine how people use adjectives in the online language. Each feature (word) has some probability of being used either positively or negatively. Summize uses five classes. The classier is a multinominal Bayes model to determine the over all 
In addition to the overall sentiments, we did a detailed analysis not at the week level but for the specific tweets that make up this sentiment.

More than 80 percent of the tweets that mentioned one of these brands expressed no sentiment.

This indicates that people are using Twitter for general

information, asking questions, along with other information seeking and sharing activities, in addition to expressing opinions about brands or products. More than 52 percent of the individual tweets were expressions of positive sentiment, while approximately 33 percent of tweets were for negative expressions of opinion.

This finding is in line with prior work. Anderson [1] showed that there was a U-shape relationship between customer satisfaction and the inclination to engage in WOM transfers. This suggests that extremely positive and satisfied and extremely negative customers are more likely to provide information relative to

consumers with more moderate experiences. sentiment of each set of twitter posts. The multinominal Bayes code picks the class with the greatest probability in winner takes all scenarios. In response to a given query, the classifier processes the latest 125 150 tweets from the result set. Duplicate tweets are ignored and non-English tweets are filtered out. The classifier analyzes the whole tweet to determine its sentiment. Summize presents a graphical presentation of the brand sentiment as shown in figure 1. Each color is the predominant sentiment for a given tweet.

\section{Results}

We then analyzed expressions of opinions or sentiments. From an analysis of 149,472 tweets over a 13-week period for 50 brands, the resulting sentiment analysis by week is shown in table 1 .

\begin{tabular}{|l|r|r|}
\hline \multicolumn{1}{|c|}{$\begin{array}{c}\text { Sentiment by } \\
\text { Week }\end{array}$} & Occurrences & \multicolumn{1}{c|}{$\%$} \\
\hline Great & 194 & $29.8 \%$ \\
\hline Swell & 200 & $30.8 \%$ \\
\hline So-so & 78 & $12.0 \%$ \\
\hline Bad & 102 & $15.7 \%$ \\
\hline Wretched & 42 & $6.5 \%$ \\
\hline No Tweets & 34 & $5.2 \%$ \\
\hline Total & 650 & $100.0 \%$ \\
\hline
\end{tabular}

table 1. Brand Sentiment by Week.

More than 60 percent of the aggregate weekly sentiments for the brands were positive (Great or Swell). Just over 22 percentages were negative (Bad or Wretched). A small percentage, (12 percent) were neutral (So-so) and an even smaller percentage of the brands (approximately 5 percent) had no tweets in a given week.
There are dissimilar motivations behind positive WOM and negative WOM utterances [1]. The major incentive for people to spread positive WOM is to gain social or self-approval. Their positive WOM utterances demonstrate their splendid purchase decisions. Additionally, altruistic behavior of sharing expertise with others has also been shown to motivate positive WOM [6]. Hostility [11] and vengeance [13] motivates dissatisfied consumers to engage in negative WOM.

We examined how sentiment changed from week to week. table 2 shows the changes in sentiment from week to week for the 50 brands over the 13-week period. Beginning with the starting week for each brand, we then calculated the change. We see that approximately 32 percent of the time there was no change from one week to the next. More than 64 percent of the time there was a change in sentiment or a change to no tweets.

\begin{tabular}{|l|r|r|}
\hline \multicolumn{1}{|c|}{ Change } & Occurrence & \% \\
\hline Change to negative & 182 & $30.3 \%$ \\
\hline Change to positive & 184 & $30.7 \%$ \\
\hline No change & 195 & $32.5 \%$ \\
\hline No tweets to negative tweets & 8 & $1.3 \%$ \\
\hline No tweets to positive tweets & 13 & $2.2 \%$ \\
\hline Tweets to no tweets & 18 & $3.0 \%$ \\
\hline Total & 600 & $100.0 \%$ \\
\hline
\end{tabular}

table 2 Sentiment Changes by Week.

This propensity of micro-blogs to change categories has important implications for businesses. Benedicktus and Andrews [2] reported that there was limited long-term effect if reputation did not decline to a lower category (e.g., from average to poor) and that many more periods of positive comments were required to rebuild trust than were required to damage it. 
Examples of tweets in each category are:

Great - Heaven on earth, the banana republic outlet store $40 \%$ off sale

Swell - you might have those forever stamps that are all good no matter the price of a current stamp

So-so - wii fit is fine, just leave enough room around you to wave your arms!

Bad - Sitting next to a "smart car" in traffic. These things just look weird. About as long as a rickshaw

Wretched - Screw you google maps. Its a good thing I have this compass and sharp stick

No Sentiment - wondering what time the banana republic store at the mall closes

\section{Discussion and Implications}

There are several implications of our research. Microblogging can be used to provide information and draw potential customers to other online media, such as Websites and blogs. As such, monitoring and leveraging micro-blogging sites concerning one's own brand and the brand of competitors provides valuable competitive intelligent information. Companies can receive positive brand exposure via followers and others who microblog about the company and products.

With micro-blog monitoring tools, companies can track micro-blog postings and immediately intervene with unsatisfied customers. Companies can get near realtime feedback, by setting up corporate accounts, from customers using micro-blog polls, and surveys. Organizations can get valuable contents and product improvement ideas by tracking micro-blog postings and following those people who follow their corporate accounts. Companies can leverage contacts made via micro-blogging service to further their branding efforts by responding to comments about the company brand.

\section{Conclusion}

It is apparent that micro-blogging services such as Twitter could become key applications in the attention economy. Given the ease of monitoring any brand' sentiment, one can view micro-blogging as a promising competitive intelligence source.

\section{References}

[1] Anderson, E. W. Customer satisfaction and word of mouth. Journal of Service Research, 1, 1 1998), 5-17.

[2] Benedicktus, R. L. and Andrews, M. L. Building trust with consensus information: The effects of valence and sequence direction Journal of Interactive Advertising , 6, 2 2006), http://www.jiad.org/article77.
[3] Davenport, T. H. and Beck, J. C. The attention economy: Understanding the new currency of business. Harvard Business Press, Cambridge, MA., 2002.

[4] Dellarocas, C. The digitization of word-of-mouth: Promise and challenges of online reputation systems. Management Science, 49, 10 2003), 1407-1424.

[5] Duana, W., Gub, B. and Whinston, A. B. Do online reviews matter? - an empirical investigation of panel data Decision Support Systems, 45, 3 2008), 1007-1016.

[6] Fehr, E. and Falk, A. Psychological foundations of incentives. European Economic Review, 46, 4 2002), 687724.

[7] Ha, H.-Y. The effects of consumer risk perception on pre-purchase information in online auctions: Brand, wordof-mouth, and customized information. Journal of Computer-Mediated Communication, 8, 1 2006).

[8] Helps, J. E., Lewis, R., Mobilio, L., Perry, D. and

Raman, N. Viral marketing or electronic word-of-mouth advertising: Examining consumer responses and motivations to pass along email. Journal of Advertising Research, 44, 2 2004), 333-348.

[9] Huberman, B. A., Romero, D. M. and Wu, F. Social networks that matter: Twitter under the microscope. Social Computing Laboratory, HP Labs 2008.

[10] Java, A., Song, X., Finin, T. and Tseng, B. Why we twitter: Understanding microblogging usage and communities. In Proceedings of the 9th WebKDD and 1st SNA-KDD 2007 workshop on Web mining and social network analysis (San Jose, California , USA, 12 August, 2007).

[11] Kimmel, A. J. Rumors and rumor control: A manager's guide to understanding and combatting rumors. Lawrence Erlbaum Associates, Mahwak, New Jersey, 2004.

[12] Milstein, S., Chowdhury, A., Hochmuth, G., Lorica, B. and Magoulas, R. Twitter and the micro-messaging revolution: Communication, connections, and immediacy 140 characters at a time. O'Reilly Media, 2008.

[13] Richins, M. L. Negative word-of mouth by dissatisfied consumers: A pilot study. Journal of Marketing, 47, Winter 1983), $68-78$. 